\title{
Causes, Solutions and References for the Subprime Lending Crisis
}

\author{
Caiying Tian \\ School of Accounting, Shandong Economic University \\ Ji'nan 250014, China \\ E-mail: tcying999@tom.com
}

\begin{abstract}
The subprime lending crisis and a series of relative problems have aroused wide concerns by various governments, especially by financial institutions, which have begun to suspect the easy money policy, the risk regulation of financial institution, and the rating agency. Based on the analysis of the cause of the subprime lending crisis, using foreign solutions for references, some advices were proposed in the article for China to face the financial crisis, i.e. guiding by the Basel agreement, disposing the relationship between financial innovation and risk regulation, establishing the independent currency policy frame, and recovering the market liquidity and confidence.
\end{abstract}

Keywords: Subprime lending crisis, Currency policy, Financial regulation

\section{Cause of formation of US subprime lending crisis}

\subsection{Too easy-money policy}

The current fluctuation of financial market has been induced by the global easy monetary management since the beginning of the year of 2002. Easy currency policy, increasingly progressive financial technology, continually ascending risk burden and financial lever boosted the current mess together. Especially, when the prices of various assets rise, the international credit can be gained freely by a cheap price. These too easy global credit conditions reflect the mutual function among the currency policy, the exchange rate system selected by some countries (especially by the developing countries with abundant labor forces), and the important change of the global financial system. From 2001 to 2006, industrial countries adopted the policy of low interest rate, which was proper without obvious inflation pressure. To some extent, the low inflation rate in this term reflected not only the reputations accumulated by the central bank in many years, but the advantageous influences from various active suppliers including largely increasing global effective labor force supply. For the exchange rate system, on the one hand, the easy money policy of developed countries might make the exchange rates of developed countries such as US depreciate comparing with the emerging market countries. On the other hand, in many emerging economies, the appreciation pressures of the currency were intervened by the easy currency policy and large-scale foreign exchange. The former would induce that the emerging market generated high asset price and more expenditures. The latter would further release the financial situation of industrial countries by the investments of official foreign exchange reverses in emerging markets on the sovereign debts of developed countries. Therefore, the currency stimulation would influence the credit growth in the global range. For the structured change of the global financial system, the change of regulation environment and the development of science and technology strongly supported the integration of assets securitization, globalization and financial industry, and further promoted easy credit conditions. The globalization would make the credit to be obtained freely in each concrete economy, and induce the regional problems to impact the whole world. In addition, the integration of financial industry could generate the scale economy when offering the credit, which could be transferred to borrowers by the form of easy financing conditions.

\subsection{Large limitation existing in the risk prevention mechanism of financial institutions}

The large limitation is mainly embodied in three aspects. First, the examination of the credit risk is ignored. After the financial institutions offer loans, they can translate loans into securities and transfer the credit risk by the asset securitization measure and the structured financial technology in the short term. In the economic ascending term, the price of house is rising, and even the borrowers can not return the loans at term, they can compensate the losses by disposing the house property. Therefore, when the financial institutions offer mortgage loans, they always think much of the credit risk not enough, and they don't strictly examine borrowers' loan repayment capacity, and they lose the basic principle of prudent management. Second, the risks are not isolated effectively. In the subprime lending crisis of US, when many financial institutions such as bank earn the incomes of agency operation by selling CDO on a commission basis, they establish the structured investment vehicles (SIV) to invest CDO specially. On the surface, the bank only offers part capitals of SIV, and most operation capitals come from the short bill financing in the market, but because of the maturity mismatching of assets and liabilities, when the market reversion happens, SIV can not obtain the market financing, the bank needs to offer capital supports, or else, SIV will go bankrupt. By this way, the risk of asset 
securitization will return to the financial institutions again. Third, the "unknown risk" will bring uncertainty. In recent years, many developed structured products bound traditional asset securities with the new products based on the subprime mortgage loan, which would generate a universe uncertainty, i.e. where the risks would centralize and how is the sensitivity of the economic cycle. When the sign of bad thing happens, except for giving attention to the risks from trading opponents, the banks would more emphasize the risks of liquidity. On the one hand, they have to continually offer financing for SIV, and on the other hand, they can not turn the offered loans into securities. Here, they begin to reconsider the previous promise to offer liquidity. Under this universe atmosphere of uncertainty, except for the products with the shortest term, banks would hardly trade in the market among banks, and other markets associated with the market among banks are also been broken.

\subsection{Imprudent ratings of rating agencies}

In the subprime mortgage loan crisis of US, for the subprime loans which can not achieve the lowest investment class $\mathrm{BBB}$, the capital manager divide these loans into the equity tranches, the mezzanine tranches, the higher tranches and the senior tranchers, and repackaging them to $\mathrm{CDO}$ and re-rate them again. According to the statistics, $75 \% \mathrm{CDO}$ obtained the same rating AAA by the US government security rating agencies, and only 7\% CDO were rated by BBB or lower class. In the crisis, many securities with the class AAA dropped to the class BBB. In fact, even if tiny change happens in the hypothesis of basic factors, the pertinence and the recovery rate of promise breaking will function on the rating highly sensitively. In addition, the data which were used to prove the initial hypothesis also had serious flaws, because the data could not cover all incomplete or false information in one credit cycle or short term. Many investors seemly though the rating could only reflect the credit risk and the high rating didn't indicate the possibility of the market liquidity and the drop of price. For the investors with this type of product, the potential losses of the investment combination which must be measured by the market price would far exceed the possible losses when purchases them. Because the rating agencies were not prudent in the rating process and gave higher rating to the assets with common quality, the subprime mortgage loans were worse and worse, and the crisis happened finally.

\subsection{Excessively easy market admittance}

Though the risk of the subprime mortgage loan is large, but financial institutions still offer subprime mortgage loans and reduce the admittance conditions of the subprime house loans because of high yield, profits and deficient risk consciousness. Some loan institutions even pushed the loan forms such as "loan without down payment" and "loan without down document", i.e. borrowers can loan capitals to purchase the house without capitals and proofs to prove their repayment abilities. The loan institutions or the loan agencies had not explain the articles about the loan and the information about the interest rate risk at large according the laws of US, so many borrowers without enough risk consciousness blindly purchased houses, which even induced many loan cheating cases happened.

\section{Solutions of main countries}

\subsection{Nationalization of financial institutions}

The Treasury Department of USA took over the Freddie and Fannie in the mess and injected capitals by the form of purchasing relative preferred stock to both of them. American Federal Reserve Committee offered emergency loans to AIG. And the government of USA began to charge the large financial assets. The government of British declared a bank rescue project with the core of nationalization, and infected capitals to various commercial banks by the form of "bank capital regulatory funds".

\subsection{Reduction of interest}

Seven largest central banks including China's Central Bank in the world declared the reduction of interest simultaneously. The central bank of Australia first reduced the interest in the past seven years, and the interest had achieved the lowest level since Dec of 2006. These reductions of interest were all "non-routine" reductions, because the interest reductions were not declared in the routine meeting of the central bank.

\subsection{Stimulating the growth of the real economy}

The president of IMF, Dominique Strau-Kahn urged that each country should use their $2 \%$ of GDP to support their own economies. APEC also promised establishing no new measures to limit the exports. EU Committee issued large economic stimulation plan to harmonize the actions of various countries to save the real economy.

\subsection{Purchasing the non-performing assets of financial institutions}

The US Congress had authorized the financial rescue plan with 900 billion dollars to purchase the non-performing assets of financial institutions in future two years, and enhanced the highest legal limitation of US national debt from 10600 billion dollars to 11300 billions dollars, which could leave capital space to implement the rescue plan. The Treasury Department of USA was especially authorized to purchase, hold and sell houses, commercial mortgage loans and relative loan support securities to help the financial institutions to strip their non-performing assets. 


\subsection{Deposit guarantee}

Various governments in Europe established protective measures of individual deposit with different scales successively to guarantee the benefit of depositors. Ireland first passed the emergency act to offer 400 billion Euros of individual deposit guarantee with two years' term for 6 largest domestic banks. Various countries in European Union also adopted similar measures. The region of Taiwan promise guarantying all personal bank deposits. Singapore guaranteed all deposits including SGD and foreign currency for all individuals and enterprises.

\subsection{Injecting capitals to the financial market}

Various central banks frequently injected capitals to the financial market with intense liquidity. Especially after Lehman Brother went bankruptcy, the injections of various countries became more active.

\subsection{Forbidding the short selling of stocks}

SEC of USA issued three new regulations limiting the short-selling behaviors to guarantee the lucidity of the short-selling operation. After that, British, Australia, France, Switzerland and Ireland all forbad the short selling.

\subsection{Cooperation of various countries}

American Federal Reserve Committee had achieved the currency exchange agreement with the central banks of Europe, Japan, British, Switzerland and Canada to release the shortage of liquidity in the financial market. China had established the "Asian Mutual Funds" with Japan and Korea to prevent the damage of "taking money and running" to the currency system by holding the others' money as the exchange reserves.

\section{References for emerging economies such as China}

\subsection{Seeking to establish the independent currency policy frame}

In the Southeast Asian Financial Crisis, the economy of US was too hot but the economy of emerging economies was too cool, and the economy of US begins to decline at present, but the economy of emerging economies is too hot, so US should reduce the interest rate to stimulate the growth and the emerging economies should carry out the deflation policy. However, because the emerging economies lack in independent currency policy (their existing currency policy is related with the currency policy of US), so they have to absorb large surplus liquidity from US under the impact of the easy currency policy of US, which not only further stimulates the hot economy, but rise the price of the primary products. The emerging economies "imports" inflation from developed countries by the financial channels and "exports" inflation to developed countries by the trade channels, so they will suffer the inflation twice and the impacting range of the subprime lending crisis quickly spread to both parties, which also make the financial currency policies of US and emerging economies in the mess. Therefore, for the emerging economies, they must gradually get rid of the currency policy relating with dollar, and establish the independent, creditable and controllable macro economy and currency index system, for example, establishing the nominal GDP growth index to warn the inflation and adopt the deflation policies in advance.

\subsection{Supporting and perfecting the new capital agreement of Basel Committee on Banking Supervision}

On the one hand, evaluate the total frame of the agreement, strengthen the encouragement mechanism, and encourage the financial institutions to develop more advanced risk measurement tool to integrate the experts' adjustments for the risk discovering, limitation, reserve and capital requirements based on the capital measurement. On the other hand, ensure the capital regulatory frame to establish enough high regulatory standards for the risk transfer, enhance the capital requirements for special securitization assets, and consider the influences of the reputation risk and the potential liquidity support obligation on the capital abundance in larger range.

\subsection{Properly disposing the relationship between financial innovation and risk regulation}

This financial crisis discovered the excessive innovation of US financial industry, i.e. the financial innovation of US had exceeded the risk identification and control ability of the financial industry and the regulatory ability of the financial regulatory department. First, the market transparence should be further enhanced. The increasing complexity and opacity of the securitization tool induced that the risk of securitized products lacked in transparence, especially the quality of the basic assets and the potential pertinence were not clear. The process to establish the rating and the rating information should be more transparent to offer stable base for investors. Second, the encouragement mechanism should be established. This financial fluctuation indicated that many participators in the initiating-decentralizing mode weakened the encouragement to the exact risk evaluation, and the encouragements for various participators (including initiator, organizer, manager, distributor, credit rating institution and investors) are different. Therefore, it is necessary to harmonize the encouragements to all participators in the asset securitization process. Third, the cognition of the risk discovering should be enhanced. The financial fluctuation indicated that many institutions investing structured products ignored the management of the non-credit risks such as market risk, liquidity risk, centralizing risk and channel risk which were related with the securitized businesses. That means the market participators need have sufficient control 
measures including effective situation analysis and pressure test program for the risk discovering. In addition, the risk discovering in the surface or the risk discovering which may be returned to the surface should be managed to avoid excessive risk centralization.

\subsection{Trying to recover the market liquidity and confidence in the first time}

IMF put forward three measuring standards for the crisis rescue, i.e. the targeted, the temporary and the timely. When the crisis happened early, time was life. In 1980s, one of experiences that Finland, Sweden and other north European countries disposed the bank crisis successfully was to quickly implement the rescue plan and stabilize investors' confidence to the financial market in time. For the rescue of the crisis, the market liquidity should be recovered in the first time. The method to solve the liquidity crisis is to ensure that the banks and other financial institutions can finance capitals from the central bank without limit, eliminate the panic in the financial market and recover the confidence in the market.

\section{References}

Huang, Xiaolong. (2007). Global Unbalance, Liquidity Surplus and Currency Crisis: Based on the Analysis View of the Unbalanced International Currency System. Journal of Financial Research. No.8.

Liu, Hui. (2008). Impact of US Financial Crisis on the World Economy and China's Policy Trend. Comparative Economic and Social Systems. No.6. P.51-56.

Peng, Junming. (2008). Impacts of US Financial Crisis. China Today Forum. No.11. P.58-64.

Robot Hiller, interpreted by Wang, Yanyan. (2008). The Subprime Solution. Comparative Economic and Social Systems. No.6. P.44-50.

Wang, Guoyue \& Du, Zhengzheng. (2008). Outline on Research Progress of Financial Regulatory Governance. Journal of Central University of Finance \& Economics. No.9. P.43-47.

Xie, Lujiang. (2008). US Subprime Crisis and Chinese Financial Reform. China Today Forum. No.10. P.37-41.

Yang, Gongqi. (2008). Analysis the Cause of Financial Crisis Based on an Economic Globalization Perspective. Modern Finance and Economics-Journal of Tianjin University of Finance and Economics. No.28(8). P.25-28.

Yang, Wenjie. (2008). Risks in the Global Economic Financing Course. Economic Herald. No.6. P.41-44.

Yan, Xuetong. (2008). World Pattern Trend and China's Opportunity. Journal of Contemporary Asia-Pacific Studies. No.5. P.7-13.

Zhang, Bin. (2008). Review of East Asian Regional Currency Cooperation. World Economics and Politics. No.10. P.26-29. 